[Transaction ]

\title{
Consumer Motivation for Brand-Switching According to Types of Fashion Products
}

\author{
Eun Jin Lim • Choon Sup Hwang ${ }^{\dagger}$ \\ Dept. of Clothing \& Textiles, Kyung Hee University
}

Received November 26, 2009; Revised (December 11, 2009; December 18, 2009); Accepted December 21, 2009

\section{패션제품 유형에 [따른 소비자 상표전환동기 차이}

\author{
임은진 · 황춘섭 ${ }^{\dagger}$ \\ 경희대학교 생활과학대학 의상학과 \\ 접수일(2009년 11월 26일), 수정일(1차 : 2009년 12월 11일, 완료일 : 2009년 12월 18일), 게재확정일(2009년 12월 21일)
}

\begin{abstract}
This study provides basic information that is needed to build marketing strategies related to consumer brand-switching, through the investigation of consumer motivations for brand-switching, as determined by the types of fashion products. The study was implemented by a descriptive survey method using a questionnaire. The survey was conducted during the period of May $11^{\text {th }}$ through July $5^{\text {th }} 2008$. A total of 184 completed responses were analyzed. All respondents were from the Seoul area and between the ages of 20 and 31. Factor analysis and Cronbach's alpha coefficients, one-way ANOVA and Duncan test were employed for the analysis of data. Significant differences were found in brand-switching motives according to the types of fashion products. For clothing, shift behavior occurred more often in conjunction with the attributes of the products itself, such as design, color, price, size, and fiber content. In general, clothes more than shoes, were likely subject to brand-switching most often on the basis of situational factors. On the other hand, for shoes, more brand-switching activities occurred because of non-product attributes, such as discounts, coupons, desire for a change, and wearing of friends. In light of the results, there is a need to differentiate brand related marketing strategies with respect to clothing and shoes. For clothing, efforts focusing on the improvement of the product attributes will be more effective in minimizing brand-switching. There is also a need to improve instructions for increasing the product understanding of salespersons as well as the ability to give advice in accordance with personal consumer characteristics. With regard to shoes, greater efforts should be given to promotional activities, and the desire of consumers for a change in order to prevent brand-switching of customers.
\end{abstract}

Key words: Motivations, Brand-switching, Types of fashion products; 동기, 상표전환, 패션제품 유형

\section{Introduction}

In accordance with the rapid industrial development, the number of brands has been increasing re-

Corresponding author

E-mail: cshwang@khu.ac.kr markably in Korea. According to a report of the Korean Intellectual Property Office (2008), during the period from the year 2000 to $2008,50,000 \sim 60,000$ new brands were registered every year, and the number of imported brands also increased continuously by 5,000 to 10,000 every year. In this tremendous number of 
brands on the rise constantly, consumers are always required to make a decision concerning which products or services to buy. They evaluate brands consistently and choose the one by which consumers themselves can most effectively express their tastes. In particular, consumers' shift behavior occurs from a particular brand to the other brands even in the same category of products owing to the occasional change of brand selection criteria ("New Generation!", 2008).

In light of these statistics, it is essential to understand consumers' motivations for brand-switching based on the satisfaction criteria and the benefits they seek. When a comprehensive understanding of motivations for brand-switching is secured, more effective marketing strategies could be made to strengthen the consumers' brand loyalty. A comprehensive understanding of the motivations for brand-switching could induce also the consumers of other competitors' brands to opt for the brand that the marketing strategy establisher wants. Many examples of previous research (Hong, 1990; Jo, 2007; Kim, 1993; Kim, 2000) have stated that consumers' purchasing behavior with regard to clothing is different according to the characteristics of the consumers themselves including brand attitude, the characteristics of products, and the purchasing situation. Considering the results, it could be easily inferred that brand-switching behavior, as a part of purchasing behavior, is related to the characteristics of consumers and products. Moreover, fashion products are no longer classified into only one category of products involving only the aspects of high-involvement and high sensitiveness (Jo, 2000). This fact suggests that consumers' motivations for brand-switching are different according to the type or specific item of fashion products. However, most of the previous brand-switching related studies considered apparel or fashion products as a whole and were not classified by specific item or type. More detailed and comprehensive information about consumers' brand-switching behavior according to each item of fashion products would be very helpful in order to establish more effective brand related marketing strategies for each item of fashion products.

Therefore the present study attempted to analyze consumers' motivations for brand-switching, as deter- mined by the kinds of fashion products in order to provide the basic information that is needed to build marketing strategies related to consumers' brandswitching.

\section{Literature Review}

\section{Fashion Products Attributes and Types}

Fashion products consist of three elements, named core elements, materiality elements, and immateriality elements. The core elements refers to the benefits that consumers seek by acquiring fashion products including motive of wearing, image of the fashion products, symbolizing social status, conformity and personality. The representative materiality elements include quality, design, material made of, brand name, and packaging. Immateriality elements imply services along with the fashion products, in other words, delivery, credit for the quality, atmosphere of the store, and kindness/advising ability of salespersons (Ahn et al., 2005; Arthur \& Stanley, 1986).

There are various criteria to apply in classifying the types of fashion products. The types of fashion products are different in accordance with the criterion applied to the classification. Those criteria include consumption ratio, tangibility, degree of involvement, purchasing behavior and product characteristics, and so forth. Ready to wear items, TPO, and fashionablity are used often as criteria for classifying fashion products (Rhee, 1997). Fashion products could be classified also more various aspects by FCB GRID model (Vaughn, 1980), which explains consumers' purchasing behavior by analysing the degree of the rationality/sensitiveness and involvement. That is, using the FCB GRID model, fashion products are classified as four types in accordance with the steps of purchase decision-making; high involvement rational products go through the steps of learn-feel-do, high involvement sensitive products go through the steps of feellearn-do, low involvement rational products go through the steps of do-learn-feel, and low involvement sensitive products go through the steps of do-feel-learn. In the past fashion products were considered as belonging to high involvement sensitive products, but 
the analysis results by the FCB GRID model shows fashion products are not always included high involvement sensitive products. According Jo (2000), casual shoes, outerwear and handbags are classified as products of high-involvement and high-sensitiveness, which belong to the second quarter dimension of FCB GRID model, having the attributes of feel-learndo and emotional. Sneakers and mountain-climbing shoes, coats and functional types of underwear are classified as products of high-involvement and rationality that belong to the first quarter dimension having the attributes of learn-feel-do and informational. Training wear, underwear for keeping the body temperature warm, and panties are classified as products of low-involvement and rationality, which belong to the third dimension having the attribute of do-learnfeel. Casual single unit wear like T-shirts and sundries are classified as products of low-involvement and sensitiveness that belong to the fourth dimension, having the attribute of do-feel-learn. Therefore, the information differentiated according to the characteristics of each item of fashion product would be very helpful for building brand-switching related marketing strategies.

On the basis of the literature review, the present study selected the variables of brand-switching behavior in view of core elements, materiality elements, and immateriality elements.

\section{Factors of Brand Switching Motivation}

\section{1) Product-related Motivational Factors}

Consumers' re-purchase and brand switching behavior is based on product attributes since consumers repurchase a product because of the product's specific attributes through which the product's maximum effect on consumption could be made. And if the preference for product attributes is reduced, consumers pursue alternatives (Lee, 2000). Kim (1993), Han et al. (1990), and Hong (1990) also reported that perceived product characteristics are highly relevant to brand-switching, and suggested that the influence of the variables related to the characteristics of fashion products on brand-switching should be considered first to forecast brand-switching behavior of consumers. Thus, these researches insist on the importance of product attributes in consumers' brand-switching behavior. For consumers, the balance of product attributes is formed by the quality perception of the product (Jacoby \& Chestnut, 1978). And both internal clues and external clues of the products have an influence on consumers' perception of product quality. According to Rhee (1997), the evaluation system consists of component factors associated with construction, benefits factors associated with consumers' expectation or pursuit, and intermediate factors related to the connection of construction-associated factors and benefit-associated factors. The variables applied to quality evaluation of fashion products imply appearance-related variables including design, materials, color, fashionablity, size, identity, and seam finish, and practicalityrelated variables including care/maintenance, durability, and comforts (Sung \& Gwon, 1996). Also, consumers' satisfaction and dissatisfaction with the attributes of fashion products made by the experience of purchasing affects brand-switching behavior. External clues (non-essential clues) of fashion products are include fashion ads, discounts, salespersons, and store image and atmosphere. These external clues affect brand-switching directly and indirectly (Jo, 2007; Kim, 1999; Oh \& Hwang, 2007; Pyun, 2004).

\section{2) Consumer Characteristics-related Factors}

Consumer characteristics-related factors of brand switching motivation include value, sensibility, attitude, involvement, and personality as formed by the social learning experiences of consumers (Pyun, 2004). Among these factors, involvement, information searching, brand attitudes, the degree of satisfaction with the products, and emotional curiosity and desire for a variety has been known as important variables associated with motivations for brand switching of fashion products (Choi \& Jo, 1995; Han et al., 1990; Hyun et al., 1991; Kim, 2001; Kotler, 1984). Especially, emotional curiosity and desire for variety have been studied often as major factors affecting consumers' brand-switching behavior with regard to fashion products. Consumers could shift brands even though they have been satisfied with the current brand due to their individual characteristic to pursue a variety of products. Generally, a variety pursue is 
carried out by buying a new brand in a later purchase, and this behavior causes a reduction in the probability to purchasing the old brand. Consumers have multidimensional needs that cause them to pursue diversity in choosing and consuming apparel products (Bloch et al., 1986; Kim \& Rhee, 2001; Lee \& Kim, 2000). The variety of brand selection behavior is a result of action made by an individual's internal motivation, and takes place among the familiar brands. On the other hand, repeated exposure to stimuli creates an increase in the degree of attracting consumers, but, at the same time, creates boredom with the stimuli. When consumers' preference to a particular brand exceeds a certain level, the degree of preference decreases and consumers feel bored with it (Kim, 2001; Lim, 2007). It now seems clear that brand switching behavior can occur due to the individual's social/emotional status, even though consumers have been satisfied with the brand.

The review of literature showed that motivations for the brand-switching of fashion products have been studied in various aspects such as product-related motivations, consumers' characteristics and purchasing behavior-related variables. However, despite of the differences in purchasing behavior among the types of fashion products, rarely have studies been made on the differences in motivations for brand-switching according to the type of fashion products. Therefore, there is a need for a study on the influence of the factors related to the attributes of fashion products and consumers' social/emotional characteristics as they relate to the brand-switching behavior of consumers.

\section{Methods}

\section{Research Problems}

This paper examined 1) the factors of brand-switching motivations and 2) the differences among the type of fashion products with regard to the contributory degree of those factors to brand-switching.

\section{Selection of Fashion Items Surveyed}

As the first step of the selection of survey items, based on the study of Jo (2000) classified fashion products by FCB GRID, the researcher selected 15 items from the products of high-involvement and high-sensitiveness. The 15 items consist of those that are considered as brand-oriented purchasing products (Donnellan, 1996), in which case, brand-switching could most likely occur. Then a preliminary survey was conducted of 100 women in the age range of 20 30 in order to find out the items for which most of consumers have a favorite particular brand buying repeatedly. This was the reason why the brand-switching could more likely occur in the items for which consumers have particular favorite brand. As a result, jeans showed the highest frequency $(76 \%)$, followed by sport shoes $(74 \%)$, shoes $(62 \%)$, coats $(58 \%)$, and jackets $(50 \%)$. Among these top five items, four items, namely, jeans, sport shoes, shoes, and jackets were selected for this study. Considering the fact that coats are limited to use in cold seasons, coats were excluded from this study, on the basis of the assumption that a limited season for use could result in the lower frequency of purchasing and brand-switching.

\section{Instrument, Sample and Data Analysis}

On the basis of previous studies (Ahn et al., 2005; Kim, 2000; Lee \& Lim, 1998; Lee \& Kim, 2000; Rhee, 1997), a self-administered questionnaire was developed, and variables were selected in order to consider three dimensions of fashion product attributes; the core elements, materiality and immateriality elements. For each type of fashion products, a total of 23 questions appeared on the questionnaire asking contributory degree of each variable to brand-switching. Five-point Likert type scales were used for most measures with $1=$ strongly disagree, and 5=strongly agree.

The survey was conducted during the period of May 11 through July 5, 2008. A total of 184 completed responses were analyzed. All the respondents were from the Seoul area and between the ages of 20 and 31. Factor analysis and Cronbach's alpha coefficients, one-way ANOVA and Duncan test were employed for the analysis of data. 


\section{Results}

\section{Factor Analysis for Brand-switching Moti- vations}

<Table 1> shows the results of the confirmatory factor analysis using Varimax rotation to test the validity and reliability of the conceptual construction of motivations for brand-switching. According to the results of factor analysis, the factors of motivation for brand-switching consisted of functional/aesthetic motivation associated with the essential elements of fashion products, situational motivations associated with external and non-essential elements of fashion products, and consumers' social/emotional curiosity motivation. The variables related to functional/aesthetic factors include design, color, materials, price, seam finishes, size, care/maintenance, and convenience (comfort). The variables associated with situational motivation for brand-switching consisted of ads, discounts, the brands that actors and actresses are wearing, kindness/advice of sales persons, displays, atmosphere of the store, out-of-stock situation, and location of the stores. Social/emotional curiosity-related motivation implies a friend's recommendation, a new brand in trend, desire for a change, boredom with the brand preferred, the brand that friends are wearing, and the rarer brand seeking.

As shown in <Table 1>, the total explained variable was $65.92 \%$, and Cronbach's alpha coefficients ranged from .813 to .899 showing moderately high reliability.

2. Differences among the Type of Fashion Products with Regard to the Contributory Degree of Functional/aesthetic Factors to Brand Switching

The results revealed some significant differences

Table 1. The results of factor analysis for brand-switching motivations

\begin{tabular}{|c|c|c|c|c|c|}
\hline $\begin{array}{l}\text { Motivations for } \\
\text { brand-switching }\end{array}$ & $\begin{array}{l}\text { I will switch brands if other brands are } \\
\text { better in terms of the following factors }\end{array}$ & $\begin{array}{l}\text { Item } \\
\text { loadings }\end{array}$ & Eigenvalues & $\begin{array}{c}\text { Variable } \\
\text { (Cumulative } \\
\text { variable) }\end{array}$ & $\begin{array}{l}\text { Cronach's alpha } \\
\text { score }\end{array}$ \\
\hline \multirow{8}{*}{$\begin{array}{l}\text { Functional/ } \\
\text { aesthetic } \\
\text { motivation }\end{array}$} & Design & .855 & \multirow{8}{*}{4.180} & \multirow{8}{*}{$\begin{array}{c}26.124 \\
(26.124)\end{array}$} & \multirow{8}{*}{.8991} \\
\hline & Color & .832 & & & \\
\hline & Material & .783 & & & \\
\hline & Size & .783 & & & \\
\hline & Price & .682 & & & \\
\hline & Care/maintenance & .685 & & & \\
\hline & Seam finishes & .567 & & & \\
\hline & Convenience (comfortable) & .563 & & & \\
\hline \multirow{7}{*}{$\begin{array}{l}\text { Situational } \\
\text { motivation }\end{array}$} & Ads. & .840 & \multirow{7}{*}{3.206} & \multirow{7}{*}{$\begin{array}{c}20.035 \\
(46.159)\end{array}$} & \multirow{7}{*}{.8127} \\
\hline & Discount/coupon & .821 & & & \\
\hline & Entertainers' clothes in TV and ads. & .781 & & & \\
\hline & Kindness/advice of sales persons & .768 & & & \\
\hline & Location of the store & .683 & & & \\
\hline & Display & .536 & & & \\
\hline & Out of stock & .459 & & & \\
\hline \multirow{6}{*}{$\begin{array}{l}\text { Social/ } \\
\text { emotional } \\
\text { curiosity } \\
\text { motivation }\end{array}$} & Friend's recommendation & .871 & \multirow{6}{*}{3.162} & \multirow{6}{*}{$\begin{array}{c}19.762 \\
(65.921)\end{array}$} & \multirow{6}{*}{.8661} \\
\hline & A new brand in trend & .826 & & & \\
\hline & Desire for a change & .784 & & & \\
\hline & Bored of the old brand (preferred before) & .727 & & & \\
\hline & Friend's wearing & .627 & & & \\
\hline & Rarer brand seeking & .549 & & & \\
\hline
\end{tabular}


among the items with regard to the contributory degree of functional/aesthetic factors to brand switching. As shown in <Table 2>, among the variables of functional/aesthetic factors of fashion products, materials, price and seam finishes did not display differences in the contributory degree toward motivation for brandswitching behavior according to the items. However, differences were found in the contributory degree of the rest of the variables according to the items. Jeans were the item for which design and color made the highest contributory degree to motivating brand-switching behavior. The items for which size made the highest contributory degree toward motivating brandswitching behavior were jeans and jackets among the types of fashion products. Jeans, more than the other items, were more likely subject to brand-switching based on color. Jeans and jackets, more than shoes, were more likely subject to brand-switching based on design, size, and convenience/comfortable factors. Among all the variables associated with functional/ aesthetic factors of fashion products, size was the only variable in which the total mean score fell above 4 on the 5-point Likert type scale. As a whole, for jeans and jacket than shoes and sport shoes, the contributory degree of functional/aesthetic factors toward motivations for brand-switching was higher. This could be a reflection of the fact that, based on the functional/aesthetic factors of products, shift behavior could be motivated more easily and more often in clothing than in shoes.

Considering the results mentioned above, more efforts in the direction of the aspects of size should be made in order to secure more effective strategies related to consumers' brand-switching behavior toward fashion products. And more concerns about design and color are needed especially to prevent jeans and jackets consumers' brand-switching behavior.

\section{Differences among the Type of Fashion Pro- ducts with Regard to the Contributory Degree of Situational Factors to Brand-switching}

The mean score of all the variables of situational factors falls between 2 and 3 on the 5-point Likert scale, while the mean score of all the variables of functional/aesthetical factors falls above 3 . The results indicate that there are differences according to the items with regard to the contribution level that all the variables of the situational factors tend to motivate toward brand-switching behavior (Table 3). In general, clothes, more than shoes, were more likely subject to brand-switching most often on the basis of situational factors. To be more detailed, for ads, kindness and advising ability of sales person, displays, out-of-stock, and easy location of stores showed a higher degree of contribution toward motivating brandswitching behavior with respect to clothing than to shoes. Among the variables of the situational factors of fashion products, the variables that display a higher contributory degree toward motivating brandswitching behavior with respect of jackets, more so than to jeans. were discounts/coupons, advising ability of salespersons, and out-of-stock. On the other hand, among the variables of the situational factors of fashion products, the only variable that displayed a low contributory degree toward motivating brandswitching behavior with regard to jeans was the category of discounts/coupons. This result could be a reflection of the fact that discounts/coupons would not be such an effective strategy to prevent the brandswitching behavior of jeans consumers. On the other hand, discounts and coupons could be effective for brand-switching behavior related strategies with respect to jackets and shoes. It was noticeable that the item affected most by advising ability and out-of-stock with respect to brand-switching was that of jackets, thus supporting the result of previous study (Jung \& Rhee, 2002). This result indicates that more concerns about salespersons' ability and stock management are needed to improve the effectiveness of brand related strategies with regard to jackets than to other fashion items.

\section{Differences among the Type of Fashion Pro- ducts with Regard to the Contributory Degree of Social/emotional Curiosity Factors of Con- sumers to Brand-switching}

The mean score of each of the variables of the social/emotional curiosity factor falls between 2 and 
Table 2. Differences in the degree to which functional/aesthetic factors contribute to brand-switching according to fashion items

$(n=184)$

\begin{tabular}{|c|c|c|c|c|}
\hline Variables & Items & M & S.D & F-value \\
\hline \multirow{5}{*}{ Design } & Jeans & $3.83 \mathrm{~A}$ & 1.045 & \multirow{4}{*}{$7.547 * * *$} \\
\hline & Jackets & $3.75 \mathrm{AB}$ & 1.082 & \\
\hline & Shoes & $3.47 \mathrm{C}$ & 1.296 & \\
\hline & Sport shoes & $3.65 \mathrm{~B}$ & 1.204 & \\
\hline & Total & 3.67 & 1.176 & \\
\hline \multirow{5}{*}{ Color } & Jeans & $3.84 \mathrm{~A}$ & 1.013 & \multirow{4}{*}{$13.104 * * *$} \\
\hline & Jackets & $3.50 \mathrm{~B}$ & 1.288 & \\
\hline & Shoes & $3.32 \mathrm{C}$ & 1.378 & \\
\hline & Sport shoes & $3.67 \mathrm{~B}$ & 1.307 & \\
\hline & Total & 3.58 & 1.278 & \\
\hline \multirow{5}{*}{ Materials } & Jeans & 3.72 & 1.075 & \multirow{4}{*}{1.339} \\
\hline & Jackets & 3.68 & 1.294 & \\
\hline & Shoes & 3.67 & 1.296 & \\
\hline & Sport shoes & 3.81 & 1.238 & \\
\hline & Total & 3.72 & 1.235 & \\
\hline \multirow{5}{*}{ Price } & Jeans & 3.64 & 1.196 & \multirow{4}{*}{2.524} \\
\hline & Jackets & 3.7 & 1.156 & \\
\hline & Shoes & 3.5 & 1.323 & \\
\hline & Sport shoes & 3.54 & 1.25 & \\
\hline & Total & 3.59 & 1.239 & \\
\hline \multirow{5}{*}{ Seam finishes } & Jeans & 3.56 & 1.111 & \multirow{4}{*}{0.864} \\
\hline & Jackets & 3.65 & 1.214 & \\
\hline & Shoes & 3.58 & 1.275 & \\
\hline & Sport shoes & 3.67 & 1.202 & \\
\hline & Total & 3.62 & 1.206 & \\
\hline \multirow{5}{*}{ Size } & Jeans & $4.15 \mathrm{~A}$ & 0.904 & \multirow{4}{*}{$5.23 * *$} \\
\hline & Jackets & $4.13 \mathrm{~A}$ & 1.022 & \\
\hline & Shoes & $3.92 \mathrm{~B}$ & 1.363 & \\
\hline & Sport shoes & $3.92 \mathrm{~B}$ & 1.232 & \\
\hline & Total & 4.02 & 1.165 & \\
\hline \multirow{5}{*}{ Care/maintenance } & Jeans & $3.56 \mathrm{AB}$ & 1.127 & \multirow{4}{*}{$3.483^{*}$} \\
\hline & Jackets & $3.65 \mathrm{~A}$ & 1.144 & \\
\hline & Shoes & $3.43 \mathrm{~B}$ & 1.23 & \\
\hline & Sport shoes & $3.44 \mathrm{~B}$ & 1.187 & \\
\hline & Total & 3.51 & 1.179 & \\
\hline \multirow{5}{*}{ Convenience/comfortable } & Jeans & $3.41 \mathrm{~A}$ & 1.233 & \multirow{4}{*}{$9.504 * * *$} \\
\hline & Jackets & $3.44 \mathrm{~A}$ & 1.248 & \\
\hline & Shoes & $3.04 \mathrm{C}$ & 1.375 & \\
\hline & Sport shoes & $3.21 \mathrm{~B}$ & 1.236 & \\
\hline & Total & 3.26 & 1.285 & \\
\hline
\end{tabular}

$* p<.05, * * p<0.1 * * * p<.001$

Duncan test: $\mathrm{A}>\mathrm{B}>\mathrm{C}$ 
Table 3. Differences in the degree to which situational factors contribute to brand-switching according to fashion items

\begin{tabular}{|c|c|c|c|c|}
\hline Variables & Items & $\mathrm{M}$ & S.D & F-value \\
\hline \multirow{5}{*}{ Ads. } & Jeans & $2.96 \mathrm{~A}$ & 1.374 & \multirow{4}{*}{$9.056 * * *$} \\
\hline & Jackets & $2.95 \mathrm{~A}$ & 1.241 & \\
\hline & Shoes & $2.58 \mathrm{C}$ & 1.188 & \\
\hline & Sport shoes & $2.78 \mathrm{~B}$ & 1.2 & \\
\hline & Total & 2.81 & 1.254 & \\
\hline \multirow{5}{*}{ Discounts/coupons } & Jeans & $2.55 \mathrm{~B}$ & 1.246 & \multirow{4}{*}{$2.965^{*}$} \\
\hline & Jackets & $2.70 \mathrm{~A}$ & 1.191 & \\
\hline & Shoes & $2.72 \mathrm{~A}$ & 1.21 & \\
\hline & Sport shoes & $2.80 \mathrm{~A}$ & 1.311 & \\
\hline & Total & 2.70 & 1.247 & \\
\hline \multirow{5}{*}{ Entertainers' cloths } & Jeans & $2.21 \mathrm{AB}$ & 1.108 & \multirow{4}{*}{$2.718^{*}$} \\
\hline & Jackets & $2.23 \mathrm{AB}$ & 1.114 & \\
\hline & Shoes & $2.15 \mathrm{~B}$ & 1.144 & \\
\hline & Sport shoes & $2.35 \mathrm{~A}$ & 1.097 & \\
\hline & Total & 2.24 & 1.117 & \\
\hline \multirow{5}{*}{$\begin{array}{l}\text { Advising ability } \\
\text { of salespersons }\end{array}$} & Jeans & $2.40 \mathrm{C}$ & 1.161 & \multirow{4}{*}{$9.574 * * *$} \\
\hline & Jackets & $2.87 \mathrm{~A}$ & 1.249 & \\
\hline & Shoes & $2.63 \mathrm{~B}$ & 1.289 & \\
\hline & Sport shoes & $2.60 \mathrm{~B}$ & 1.236 & \\
\hline & Total & 2.63 & 1.246 & \\
\hline \multirow{5}{*}{$\begin{array}{l}\text { Kindness of } \\
\text { salespersons }\end{array}$} & Jeans & $2.78 \mathrm{~A}$ & 1.284 & \multirow{4}{*}{$14.214 * * *$} \\
\hline & Jackets & $2.85 \mathrm{~A}$ & 1.247 & \\
\hline & Shoes & $2.38 \mathrm{~B}$ & 1.259 & \\
\hline & Sport shoes & $2.50 \mathrm{~B}$ & 1.214 & \\
\hline & Total & 2.61 & 1.262 & \\
\hline \multirow{5}{*}{ Displays } & Jeans & $3.01 \mathrm{~A}$ & 1.211 & \multirow{4}{*}{$17.459 * * *$} \\
\hline & Jackets & $3.27 \mathrm{~B}$ & 1.216 & \\
\hline & Shoes & $2.86 \mathrm{C}$ & 1.366 & \\
\hline & Sport shoes & $2.68 \mathrm{C}$ & 1.264 & \\
\hline & Total & 2.93 & 1.287 & \\
\hline \multirow{5}{*}{ Out-of-stock } & Jeans & $2.66 \mathrm{~B}$ & 1.225 & \multirow{4}{*}{$19.167 * * *$} \\
\hline & Jackets & $2.88 \mathrm{~A}$ & 1.196 & \\
\hline & Shoes & $2.30 \mathrm{C}$ & 1.148 & \\
\hline & Sport shoes & $2.50 \mathrm{~B}$ & 1.175 & \\
\hline & Total & 2.57 & 1.201 & \\
\hline \multirow{5}{*}{ Location of store } & Jeans & $2.89 \mathrm{~A}$ & 1.225 & \multirow{4}{*}{$10.899 * * *$} \\
\hline & Jackets & $2.68 \mathrm{~B}$ & 1.137 & \\
\hline & Shoes & $2.45 \mathrm{C}$ & 1.061 & \\
\hline & Sport shoes & $2.62 \mathrm{~B}$ & 1.162 & \\
\hline & Total & 2.65 & 1.154 & \\
\hline
\end{tabular}

$* p<.05, * * * p<.001$

Duncan test: $\mathrm{A}>\mathrm{B}>\mathrm{C}$ 
3 , showing a tendency similar to that of the situational factors (Table 4). Curiosity for a new brand in trend, boredom with an old brand, and desire for a rarer brand motivated brand-switching behavior more with respect to jeans than in other items. Desire for a change, and friends' wearing motivated brand-switching behavior more with regard to shoes than to jeans. This result could be a reflection of the fact that brand image related variables motivate brand-switching be- havior more with respect to jeans than to other types of fashion products, while consumers' characteristics related variables such as friends' wearing or desire for a change, motivate brand-switching more in the case of shoes than in clothing. Therefore, more concern about brand image management is needed for jeans, and more effort to understand consumers' emotional characteristics is needed for more effective brand related strategies toward the marketing of shoes products.

Table 4. Differences in the degree to which social/emotional curiosity factors of consumers contribute to brandswitching according to fashion items

\begin{tabular}{|c|c|c|c|c|}
\hline Variables & Items & $\mathrm{M}$ & S.D & F-value \\
\hline \multirow{5}{*}{$\begin{array}{c}\text { Friends' } \\
\text { recommendation }\end{array}$} & Jeans & 2.87 & 1.198 & \multirow{4}{*}{0.989} \\
\hline & Jackets & 2.85 & 1.346 & \\
\hline & Shoes & 2.76 & 1.284 & \\
\hline & Sport shoes & 2.75 & 1.261 & \\
\hline & Total & 2.80 & 1.274 & \\
\hline \multirow{5}{*}{ Wearing of friends } & Jeans & $2.13 \mathrm{~B}$ & 1.077 & \multirow{4}{*}{$4.716^{* * *}$} \\
\hline & Jackets & $2.32 \mathrm{~A}$ & 1.153 & \\
\hline & Shoes & $2.41 \mathrm{~A}$ & 1.253 & \\
\hline & Sport shoes & $2.37 \mathrm{~A}$ & 1.132 & \\
\hline & Total & 2.32 & 1.162 & \\
\hline \multirow{5}{*}{ For a change } & Jeans & $2.21 \mathrm{~B}$ & 1.124 & \multirow{4}{*}{$6.613 * * *$} \\
\hline & Jackets & $2.19 \mathrm{~B}$ & 1.155 & \\
\hline & Shoes & $2.37 \mathrm{~A}$ & 1.228 & \\
\hline & Sport shoes & $2.49 \mathrm{~A}$ & 1.229 & \\
\hline & Total & 2.33 & 1.196 & \\
\hline \multirow{5}{*}{$\begin{array}{l}\text { Curiosity for } \\
\text { a new brand in trend }\end{array}$} & Jeans & $2.82 \mathrm{~A}$ & 1.143 & \multirow{4}{*}{$3.657^{*}$} \\
\hline & Jackets & $2.74 \mathrm{AB}$ & 1.391 & \\
\hline & Shoes & $2.59 \mathrm{~B}$ & 1.206 & \\
\hline & Sport shoes & $2.60 \mathrm{~B}$ & 1.218 & \\
\hline & Total & 2.68 & 1.244 & \\
\hline \multirow{5}{*}{ Bored of old brand } & Jeans & $2.47 \mathrm{~A}$ & 1.126 & \multirow{4}{*}{$2.841^{*}$} \\
\hline & Jackets & $2.36 \mathrm{AB}$ & 1.212 & \\
\hline & Shoes & $2.25 \mathrm{~B}$ & 1.144 & \\
\hline & Sport shoes & $2.40 \mathrm{AB}$ & 1.178 & \\
\hline & Total & 2.37 & 1.168 & \\
\hline \multirow{5}{*}{ Desire for a rarer brand } & Jeans & $2.60 \mathrm{~A}$ & 1.136 & \multirow{4}{*}{$15.805 * * *$} \\
\hline & Jackets & $2.15 \mathrm{~B}$ & 1.079 & \\
\hline & Shoes & $2.14 \mathrm{~B}$ & 1.042 & \\
\hline & Sport shoes & $2.24 \mathrm{~B}$ & 1.107 & \\
\hline & Total & 2.27 & 1.104 & \\
\hline
\end{tabular}

$* p<.05, * * p<0.1 * * * p<.001$

Duncan test: $\mathrm{A}>\mathrm{B}>\mathrm{C}$ 


\section{Conclusions}

The present study was implemented in order to analyze the motivations for brand-switching of fashion products by consumers, through a descriptive survey method using questionnaire. The results and implications are as follows:

Significant differences were found in brand-switching motives according to the kinds of fashion products.

As a whole, for jeans and jacket more than for shoes and sport shoes, the contributory degree of functional/aesthetic factors toward motivation for brand-switching were higher. Among all the variables associated with the functional/aesthetic factors of fashion products, size was the only variable of which the total mean score fell above 4 on the 5point Likert type scale. Therefore, more efforts with regard to the aspects of size should be made in order to secure effective strategies related to brand-switching behavior. Also, more concerns about design and color are needed especially to prevent jeans and jackets consumers' brand-switching behavior.

In general, clothes, more than shoes, were most likely to be subject to brand-switching based on situational factors. On the other hand, among the variables of the situational factors, discounts/coupons were the only variable that showed a low contributory degree toward motivating brand-switching behavior with respect to jeans. The item affected most by advising ability and out-of-stock with respect to brandswitching was jackets. Therefore, discounts/coupons would not be such an effective strategy to prevent brand-switching behavior of jeans consumers. On the other hand, discounts and coupons could be effective for brand-switching behavior related strategies with respect to jackets and shoes. More concern about salespersons' ability and stock management are needed to improve the effectiveness of brand related strategies with respect to jackets than to the other fashion items.

Brand image related variables motivate brandswitching behavior more with regard to jeans than to other types of fashion products, while consumers' characteristics related variables such as friends' wear- ing or desire for a change shoes motivate brand-switching more often in the case of shoes than in clothing. Therefore, greater attention should be applied toward brand image management for jeans, and more efforts to understand consumers' emotional characteristics are needed for more effective brand related strategies with respect to shoe products.

\section{References}

Ahn, K. H., Hwang, S. J., \& Jung, C. J. (2005). Fashion marketing. Seoul: Suhaksa.

Arthur, A. W., \& Stanley, G. (1986). Fashion advertising \& promotion. New York: Fairchild Publication.

Bloch, P. H., Sherrell, D. C., \& Ridgway, N. M. (1986). Consumer search: An extended framework. Journal of Consumer Research, 13, 119-120.

Choi, K. S., \& Jo, P. G. (1995). The relationship between clothing involvement and brand loyalty. The Research Journal of the Costume Culture, 3(2), 449-458.

Donnellan, J. (1996). Merchandise buying and management. New York: Fairchild Publications.

Han, M. H., Chang, D. R., \& Kim, I. T. (1990). Mediating effect of consumer product involvement on brand switching. Journal of Consumer Studies, 1(1), 108-126.

Hong, G. S. (1990). A study on consumer' variety seeking behavior. Unpublished master's thesis, Seoul National University, Seoul.

Hyun, Y. J., Chaiy, S. I., \& Jeung, J. H. (1991). The effects of information search on brand switch behavior. Journal of Consumer Studies, 2(1), 76-93.

Jacoby, J., \& Chestnut, R. W. (1978). Brand loyalty measurement and management. New York: John Wiley \& Sons INC.

Jo, E. Y. (2000). An analysis on the appropriateness factors and the purchase intention of internet shopping for fashion goods based on goods classification of the FCB GRID Model. Unpublished doctoral dissertation, Chung Ang University, Seoul.

Jo, S. N. (2007). The effects of multi-shop's store image on the store loyalty and brand switching behavior. Journal of Korean Home Economics Association, 45(1), 58-59.

Jung, H. S., \& Rhee, E. Y. (2002). Consumers' store patronage mix behavior by fashion product type. Journal of the Korean Society of Clothing and Textiles, 26(8), $1128-1140$.

Kim, C. H. (1999). Market segmentation by the types of variety pursue behavior. Unpublished master's thesis, Yonsei University, Seoul.

Kim, G. C. (1993). The effects of situational variables on the consumer's brand choice behavior. Unpublished doctoral dissertation, Inha University, Inchon. 
Kim, H. D. (2000). A study on the influence of the brand switching by consumer and product characteristics and degree of involvement. Korean Industrial Economics Association, 13(4), 445-468.

Kim, M. K. (2001). The type of consumers brand switching on fashion goods and response to marketing communication. Journal of the Korean Society of Clothing and Textiles, 25(4), 685-696.

Kim, S. A., \& Rhee, Y. S. (2001). The consumer's motive of variety seeking and variety seeking behavior in clothing products-In relation to fashion interests and clothing purchase behavior among consumer groups-. Journal of the Korean Society of Clothing and Textiles, 25(2), 901-912.

Korean Intellectual Property Office. (2008). Annual report of intellectual property statistics, Korean statistics report. kosis. Retrieved July 25, 2008, from http://www.kosis.kr

Kotler, P. (1984). Marketing management: Analysis, planning, and control (5th ed.). New Jersey: Prentice-Hall.

Lee, D. H. (2000). Factors affecting brand maintenance and brand-switching. Journal of Distribution Research, 5(1), $1-19$.

Lee, S. H., \& Lim, S. J. (1998). A study on consumers' evaluation and compliant to domestic apparel products. The Research Journal of the Costume Culture, 6(1), 110-
120.

Lee, S. J., \& Kim, M. K. (2000). The type of consumer's brand switching on fashion goods and relationship of fashion-related variables. Journal of the Korean Society of Costume, 50(7), 181-193.

Lim, K. B.(2007). The effect of clothing involvement and loyalty orientation on the information search behavior. Journal of the Korean Society of Clothing and Textiles, 31(9), 1396-1407.

New generation! Prefer to substance than a new one. (2008, June 15). CNB News. Retrieved September 14, 2008, from http://cnbnews.com/category/read.html?bcode= 41766

Oh, S. M., \& Hwang, S. J. (2007). The influence of consumer's brand loyalty, competitor's brand price, and discount on brand switching for apparel products. Journal of the Korean Society of Clothing and Textiles, 31(3), 440-450.

Pyun, C. G. (2004). Motivation theory of consumer behavior. Seoul: Hyosan Management Institute.

Rhee, E. Y. (1997). Fashion marketing. Seoul: Gyomunsa.

Sung, S. G., \& Gwon, O. K. (1996). Consumption offashion products. Seoul: Gyomunsa.

Vaughn, R. (1980). How advertising works: A planning model. Journal of Advertising Research, 20(5), 27-33.

\section{요 약}

본 연구는 상표전환 관련 마케팅전략 수립에 필요한 기초정보를 제공하고자, 패션제품 소비자의 상표 전환동기를 품목별로 고찰 비교하였다. 질문서를 이용한 조사연구법에 의해 이루어졌으며, 자료수집 기 간은 2008년 5월 6월이었고, 총 4개 패션품목에 대한 184 부의 응답자료가 요인분석, Cronbach's alpha coefficients, ANOVA 및 Duncan test에 의해 이루어졌다. 패션제품의 기능/미적 동기 및 상황적 동기와, 소 비자의 사회/정서적 호기심 동기 측면에서의 상표전환동기가 패션제품 품목에 따라 유의한 차이가 있음 이 확인되었다. 전체적으로, 기능/미적 요인들이 상표전환에 기여하는 정도는 청바지와 재킷의 경우가 구 두와 운동화보다 더 높았다. 기능/미적 측면의 동기와 관련된 모든 변수 중 사이즈의 영향력이 가장 높게 나타나, 패션제품 소비자의 상표전환 관련 마케팅전략에는 제품 사이즈에 대한 관심이 매우 필요함을 시 사하였다. 대체로 상황적 요인도 신발보다 의복의 경우에 상표전환동기로 더 많이 작용하였다. 그러나 디 스카운트/쿠폰 제공 등의 촉진전략 변수가 상표전환동기로 기여하는 정도는 청바지가 운동화와 구두 및 재킷보다 낮게 나타났다. 한편 판매자의 조언능력이나 품절상황이 상표전환동기로 가장 높게 기여하는 품목은 재킷인 것으로 나타났다. 친구의 조언이나 변화에 대한 욕구 및 타 브랜드에 대한 호기심 등의 소 비자 특성 관련 변수가 상표전환동기로 기여하는 정도는 신발류의 경우가 의류에서보다 더 높은 것으로 나타났다. 이러한 상표전환동기의 차이는 패션제품 품목에 따라 차별화된 상표전환 관련 마케팅전략의 필요성을 보다 구체적으로 보여주고 있다고 판단된다. 아울러, 본 연구의 한계점으로 남은 연령과 성별에 따른 각 제품의 상표전환동기에 대한 연구가 뒤따라야 할 것으로 사료된다. 또한 상표전환의 정도를 보다 효율적으로 측정할 수 있는 도구의 개발이 이루어져서 보다 다양한 측면의 상표전환동기 연구가 이루어 져야 할 것으로 사료된다. 